\title{
Body composition and net requirements of protein and energy for weight gain of Nellore and crossbreed steers finished under grazing ${ }^{1}$
}

\author{
Nivaldo de Faria Sant' Ana $^{2}$, Carlos Augusto de Alencar Fontes ${ }^{2}$, Renata Soares Tavares \\ da Silva ${ }^{2}$, Carolina de Souza Garcia ${ }^{2}$, Ricardo Augusto Mendonça Vieira ${ }^{2}$, \\ Tiago Cunha Rocha ${ }^{2}$
}

\footnotetext{
${ }^{1}$ Projeto de pesquisa financiado com recursos obtidos juntos ao CNPq - Edital Universal 2006 e FAPERJ - Edital $n^{\circ} 19 / 2008$. 2 Universidade Estadual do Norte Fluminense - UENF.
}

ABSTRACT - The objective of this work was to evaluate body composition and net requirements of protein and energy for weight gain of Nellore and crossbred F1 Limousin-Nellore steers finished on Mombasa grass pastures. Mombasa grass (Panicum maximum) pastures were managed under intermitent stocking during the rainy season, with a forage offer of $8 \%$ of the body weight (BW) based on the dry matter of green leaves. Twenty-four steers were used: 12 were Nellore (386 kg SBW) and 12 were F1 Limousin-Nellore (397 kg SBW). Changes in body composition in a 104-day experimental period were evaluated according to the comparative slaughter method. After slaughter, all body components were weighed and representative samples of carcass (HH section) and non-carcass tissues were collected, processed and chemically analyzed to determine body contents of protein, fat and energy in each animal. Linearized allometric equations were fitted to describe the pattern of growth of body components as a function of empty body weight of the animals. The obtained equations were derived to predict net requirements of protein and energy for weight gain. There were no differences between Nellore and crossbreed steers regarding to protein deposition. Nellore animals tended to a greater deposition of energy on weight compared to crossbred animals. It is possible to obtain well finished carcass in Nellore and crossbred steers with a greater weight on tropical pastures with an adequate supply of leaves.

Key Words: Limousin, Mombasa grass

\section{Composição corporal e exigências líquidas de proteína e energia para ganho de peso de novilhos nelores e mestiços terminados a pasto}

\begin{abstract}
RESUMO - Este trabalho foi conduzido com o objetivo de avaliar a composição corporal e as exigências líquidas de proteína e energia para ganho de peso de novilhos Nelore e mestiços $1 / 2$ Limousin-Nelore terminados em pastagem de capimmombaça. A pastagem de capim-mombaça (Panicum maximum) foi manejada em regime de lotação intermitente durante a época chuvosa, com oferta de forragem de $8 \%$ do peso corporal (PC), com base na matéria seca de folhas verdes. Foram utilizados 24 novilhos: 12 da raça Nelore (386 kg PCJ) e 12 mestiços 1/2Limousin-Nelore (397 kg PCJ). As mudanças de composição corporal no período de 104 dias foram avaliadas pelo método do abate comparativo. Após o abate, foram pesados todos os componentes corporais e coletadas, processadas e analisadas quimicamente amostras representativas da carcaça (seção HH) e dos tecidos não-componentes da carcaça, visando estimar os conteúdos corporais de proteína, gordura e energia em cada animal. Foram ajustadas equações alométricas linearizadas para descrever o padrão de crescimento dos componentes corporais em função do peso de corpo vazio dos animais. As equações obtidas foram derivadas objetivando a predição das exigências líquidas de proteína e energia para ganho de peso. Não houve diferenças entre os animais nelores e mestiços quanto à deposição de proteína. Os animais nelores tenderam à maior deposição de energia no ganho em comparação aos mestiços. É possível obter carcaças bem acabadas em bovinos nelores e mestiços de maior porte em pastagens tropicais com oferta adequada de folhas.
\end{abstract}

Palavras-chave: capim-mombaça, Limousin

\section{Introduction}

The prediction of body composition in cattle is the basis for estimating the net requirements of nutrients and energy for gain in these animals (Fox \& Black, 1984). In Brazil, despite recent advances (Valadares Filho et al., 2006), there are no national standards for cattle feeding, thus, the nutritional requirements are usually calculated 
based on empirical equations established in other countries, with production systems that are different from the Brazilian reality (Silva et al., 2002).

Accordingly, in the US feeding system (NRC, 2000), one of the most feeding system used in Brazil for beef cattle, the equations for predicting body composition were adjusted on information relating to British breeds in confinement. Moreover, the extensive production systems of the zebu cattle under grazing still predominate in Brazil.

The crossing of Nellore, widely distributed in Brazil, with large frame European breeds, with high potential for meat production, would be an interesting alternative to increase the productivity of beef cattle (Fontes, 1995). However, because of the positive association between yield potential and nutritional requirements (Fox \& Black, 1984), the use of crossbred might not be advantageous in some breeding phases, especially in the finishing phase of the animals.

The relationship between the nutritional requirements of different genetic groups would not be fixed but subject to genotype $\times$ environment interaction (Sprinkle et al., 1998), mainly for feeding level (Fortin et al., 1980).

The pastures in general, and in particular the tropical ones (Ribeiro et al., 2008), would be a limiting environment for animal performance, mainly from a nutritional standpoint (Poppi \& Mclennan, 1995). The nutritional requirements of grazing animals would differ markedly from that observed for confined animals (Zervoudakis et al., 2002), due not only to lower performance of animals on pasture, but also to the effect of grazing itself (Hata et al. 2005).

This study was conducted to evaluate the body composition and net requirements of protein and energy for weight gain of Nellore and crossbred Limousin-Nellore grazing on Mombasa grass.

\section{Material and Methods}

The research was conducted in Campos dos Goytacazes

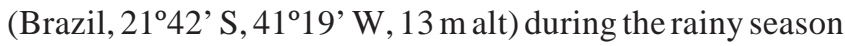
and it lasted for 104 days (December - April). It was used an experimental area of 6.5 ha, on a flat terrain, cultivated with Mombasa grass (Panicum maximum cv. Mombaça) and divided with electric fences into 13 paddocks of 0.5 ha each.

The pasture was managed under rotational stocking with periods of grazing and rest of 2 and 24 days, respectively. During the experimental period, four 26-day grazing cycles were completed. The daily herbage allowance was maintained at around $8 \mathrm{~kg}$ of green leaves dry matter (DM) per $100 \mathrm{~kg}$ of body weight (BW), using similar put and take steers.

Biomass of the green leaves was estimated the day before grazing initiated in paddocks representative of the experimental area, according to methodology described by Ribeiro et al. (2008). Maintenance fertilization was 80 kg/ha of nitrogen, split into two equal applications of ammonium sulfate.

The experimental animals were 24 steers, 12 Nellore and 12 crossbred $1 \frac{1}{2}$ Limousin-Nellore, with shrunk body weight (SBW), averaging $386 \pm 3.8$ and $397 \pm 9.7 \mathrm{~kg}$, respectively. The animals were purchased from the same commercial breeder in the region, constituting a homogeneous portion within each genetic group (Table 1). Animals were identified, subjected to the control of endo and ectoparasites and adapted to pastures and to the experimental management three weeks before the experimental period.

The changes in body composition were evaluated by using the comparative slaughter method, described by Lofgreen \& Garrett (1968) and adapted for grazing animals by Fontes et al. (2005a). Within each genetic group, the animals were divided randomly into three groups of four animals: reference, restricted feeding and ad libitum feeding.

The reference group was slaughtered at the beginning of the experimental period. The animals under restricted feeding, during the experimental period, had access to pasture for 3.5 hours daily (8:30 a.m. to 12 p.m.). For the rest of the day, they were kept in covered individual pens $\left(12 \mathrm{~m}^{2}\right)$ with drinker, $100 \mathrm{~m}$ away from the pasture. Animals fed ad libitum were kept on pasture full time. The objective of this management was to maintain the intake of restricted animals close to the requirement for maintenance

Table 1 - Initial body composition, means and standard errors, and shrunk body weight ranges

\begin{tabular}{|c|c|c|c|c|c|c|}
\hline & \multicolumn{3}{|c|}{ Initial chemical composition ${ }^{1}$} & \multicolumn{3}{|c|}{ Weight Range (SBW) ${ }^{2}$} \\
\hline & Protein & Fat & Energy & Lower & Average & Upper \\
\hline Nellore & $20.1 \pm 0.25$ & $10.1 \pm 0.55$ & $2.1 \pm 0.05$ & 365 & 411 & 474 \\
\hline Crossbred & $20.6 \pm 0.45$ & $8.8 \pm 0.95$ & $2.0 \pm 0.05$ & 345 & 432 & 527 \\
\hline
\end{tabular}

${ }^{1}$ Reference group ( $\mathrm{n}=8$ ); protein and fat (\% EBW); energy (Mcal/kg EBW); and respected standard errors.

2 Weight ranges at slaughter of the 24 experimental steers (reference, restricted and ad libitum groups). 
(Fontes et al., 2005a). Accordingly, during the experimental period, the average daily weight gain (BW) of animals on restricted and ad libitum feeding was 0.12 and $0.57 \mathrm{~kg} /$ day, respectively.

Animals on restricted and ad libitum feeding, from both genetic groups, were kept together in the pasture, taking the same paddock daily. In the pasture, they had access to shade, water and commercial mineral mixture. The SBW was recorded at the beginning and after each grazing cycle, after 16 hours without food and water. At the end of the experimental period, all animals from both groups were slaughtered.

The slaughter was carried out on commercial slaughterhouse according to federal standards prescribed for humane slaughter of cattle (Brazil, 2000). After slaughter of each animal, the components of the gastrointestinal tract (rumen, reticulum, omasum, abomasum and small and large intestines) were emptied, washed, separated from the visceral fat (mesenteric and omental) and weighed. After that, samples were taken proportional to the weight of each component, which were mixed and ground (meat industrial grinder) to obtain a representative sample of the gastrointestinal tract.

Tongue, trachea, esophagus, liver, heart, kidneys, lungs, spleen, industrial meat and the reproductive system were separated, weighed and sampled proportionately. The individual samples of these components were grouped in a proportionally to the total weight, mixed and ground to obtain a representative sample of the organs. Trimmings (pelvic, kidney and heart fat, more injured tissues of the carcass and noncarcass, all from cleaning the carcass in the slaughterhouse) and visceral fat (mesenteric and omental) were proportionately pooled, mixed and ground to obtain a representative sample of greasy waste.

Leather, blood, head, tail and feet were separated, weighed and sampled proportionately (using a saw in the case of bone). The head and feet were collected from only one representative animal in each breed and management. The composite samples of the gastrointestinal tract, organs and the greasy waste and the individual samples of leather, blood, head, tail and feet were representative of noncarcass tissues (NCAR).

Hot carcasses were weighed and taken to the cold chamber where they remained for 18 hours at $-5^{\circ} \mathrm{C}$. After carcass data collection, the 9-10-11 rib section (HH section) was removed from the left side of each carcass as outlined by Hankins \& Howe (1946). The HH section was separated into lean meat, bone (plus tendon) and fat, components consisting mostly by muscle, bone and adipose tissues, respectively.
The separate components of the $\mathrm{HH}$ section were weighed, ground in a meat grinder (or sawed into small pieces, in the case of bones) and sampled separately. Samples of lean meat, bone and fat were considered representative of the carcass (CAR). The empty body weight (EBW) of the animals was obtained by adding carcass and noncarcass weights. Also in the left side of carcass, it was measured the rib eye area, between the $12^{\text {th }}$ and $13^{\text {th }}$ ribs, in the cross-section of the longissimus dorsi muscle.

Samples from all animal tissues were previously defatted, according to methodology described by Kock \& Preston (1969), then the samples were ground in a ball mill and analyzed for dry matter, crude protein, ether extract and ash (Silva \& Queiroz, 2002).

Thus, the contents $(\mathrm{kg})$ of protein and fat in empty body, carcass and noncarcass were obtained. The energy content (Mcal) in the EBW, carcass and noncarcass were estimated from the contents of protein and fat and their caloric equivalents were: 5.6405 and $9.3929 \mathrm{Mcal} / \mathrm{kg}$, respectively, for protein and fat (ARC, 1980). In this study, manually separable carcass fat (subcutaneous + intermuscular) was referred as "physical" and analytical fat (ether extract) was referred as "chemical".

Linearized allometric equations were fitted to describe the growth pattern of body components $(\mathrm{Y})$ of reference and ad libitum animals $(\mathrm{n}=16)$, as a function of EBW (ARC, 1980):

$\log _{10} \mathrm{Y}=\log _{10} \alpha+\gamma \times \log _{10} \mathrm{X}$

in which $\mathrm{X}=$ empty body weight (EBW), $\mathrm{Y}=$ protein $(\mathrm{kg})$, chemical fat (kg) and energy (Mcal) content (in empty body, carcass and noncarcass), ribeye area $\left(\mathrm{cm}^{2}\right)$, visceral fat $(\mathrm{kg})$, physical fat $(\mathrm{kg})$ and of carcass lean meat $(\mathrm{kg})$; and $\alpha, \gamma$ parameters of the equation.

The allometric coefficient $(\gamma)$, dimensionless, represents the ratio between the instantaneous relative growth rates of ' $\mathrm{Y}$ ' and ' $\mathrm{X}$ ' ( $d y / y d t: d x / x d t)$ (Kidwell et al., 1952). If $\gamma>1$, then $d y / y d t>d x / x d t$, that is, the part "Y" grows at a rate greater than the whole " $\mathrm{X}$ " (early growth); on the contrary, if $\gamma<1$, then $d y / y d t<d x / x d t$, with the part growing at rates lower than the whole (late growth). If $\gamma=0$, there were no differences between the growth rates of ' $X$ ' and ' $\mathrm{Y}$ ' $(d y / y d t=d x / x d t)$, indicating that the growth rates of part and the whole are similar (isometric growth).

The adjusted equations for protein and energy content in the empty body were used to predict the body concentration (g/kg EBW, Mcal/kg EBW) of these components, within the evaluated interval of weights (Table 1). In addition, the net requirements of protein and energy (g/kg, Mcal/kg) for weight gain were obtained by the first derivative of equation 1 (ARC, 1980). 
$\mathrm{Y}^{\prime}=\hat{\gamma} \times \hat{\alpha} \times \mathrm{X}^{(\hat{\gamma}-1)}$

in which: $\mathrm{X}=$ empty body weight (EBW), $\mathrm{Y}=$ protein $(\mathrm{kg})$ and energy (Mcal) content in empty body, and $\alpha, \hat{\gamma}$ parameter estimates (obtained from the fit of equation 1).

Linear equations were adjusted for the relationship between BW, SBW, EBW and carcass weight (CARW) of experimental animals.

The regression equations were fitted by using PROC REG of SAS ${ }^{\circledR}$ statistical package. The effect of genetic group was tested by using the general model:

$$
\mathrm{Y}_{\mathrm{i}}=\beta_{0}+\beta_{1} \mathrm{X} 1_{\mathrm{i}}+\beta_{2} \mathrm{X} 2_{\mathrm{i}}+\beta_{3} \mathrm{X} 1_{\mathrm{i}} \mathrm{X} 2_{\mathrm{i}}+\varepsilon_{\mathrm{i}} \text {, }
$$

for observations $i=1,2, \ldots$, n; in which: $Y_{i}=$ dependent variable $(\mathrm{Y})=\mathrm{X} 1_{\mathrm{i}}$ quantitative variable $(\mathrm{EBW}) ; \mathrm{X} 2_{\mathrm{i}}=$ qualitative variable "dummy", with values 0 for Nellore $\left(\mathrm{Y}_{\mathrm{i}}=\beta_{0}+\beta_{1} \mathrm{X} 1_{\mathrm{i}}\right)$ and 1 for crossbreed $\left(\mathrm{Y}_{\mathrm{i}}=\left(\beta_{0}+\beta_{2}\right)+\left(\beta_{1}+\beta_{3}\right) \mathrm{X} 1_{\mathrm{i}}\right) ; \mathrm{X} 1_{\mathrm{i}} \mathrm{X} 2_{\mathrm{i}}=$ interaction effect; and $\varepsilon i=$ random error ( which was allowed as an additive even with the logarithmic transformation of allometric equation).

If $\beta_{3} \neq 0$, the genetic groups differed on the regression coefficient; if $\beta_{2} \neq 0$, the genetic groups differed on the intercept; and if $\beta_{2}=0$ and $\beta_{3}=0$, there was no difference between the coefficients and intercepts, and only one equation was adjusted, considering the results of both genetic groups together. The null hypothesis for the parameter estimates $\left(\mathrm{H} 0: \hat{\beta}_{0}=0, \hat{\beta}_{1}=0, \hat{\beta}_{2}=0, \hat{\beta}_{3}=0\right)$ were tested by $t$ test (5\%).

For statistical analysis of body proportions (\% EBW) of the gastrointestinal tract and internal organs, it was used the following model:

$$
\mathrm{Y}_{\mathrm{ijk}}=\mu+\mathrm{G}_{\mathrm{i}}+\mathrm{F}_{\mathrm{j}}+\mathrm{GF}_{\mathrm{ij}}+\varepsilon_{\mathrm{ijk}},
$$

in which: $\mathrm{Y}_{\mathrm{ijk}}=$ information about the animal $k$, in feeding management $j$, in genetic group $i, \mu=$ overall mean, $G_{i}=$ effect of genetic group $i$, being $i=1$, Nellore and 2, crossbreed; $\mathrm{F} j$ = effect of feeding management, $\mathrm{j}=1$, reference, 2 , ad libitum and 3,restricted; GFij = interaction effect $\mathrm{j} ; \varepsilon_{\mathrm{ijk}}=$ random error.

\section{Results and Discussion}

No significant differences $(\mathrm{P}>0.05)$ were obtained among Nellore and crossbred animals considering the relationship between the body (BW, SBW and EBW) and carcass (CARW) weights. Thus, equations were jointly adjusted $(\mathrm{n}=24)$ for both genetic groups: $\mathrm{SBW}=-37.71+1.02 \mathrm{BW}$ $\left(r^{2}=0.96, C V=2.09 \%\right) ; E B W=-10.41+$ SBW0.85 $\left(r^{2}=0.95\right.$, $\mathrm{CV}=2.47 \%)$, and CARW $=-3.13+0.56 \mathrm{SBW}\left(\mathrm{r}^{2}=0.82\right.$, $\mathrm{CV}=2.96 \%)$.

Additionally, to better understand the relationship of body and carcass weight of restricted and ad libitum animals, it was adjusted linear equations $(\mathrm{n}=16)$ in which the intercept was suppressed $(\mathrm{y}=\zeta \times \mathrm{x})$ (Table 2). The ad libitum animals had a higher proportion of empty body and carcass in body weights (BW and SBW) compared to restricted group, which were superior to the digesta (Table 2).

For the relationships SBW/BW and EBW/SBW in ad libitum animals, the NRC (2000) used the coefficients of 0.96 and 0.89 , respectively, which implies in content of digesta lower than those observed in this study (Table 2). According to Rohr \& Daenicke (1984), the digesta can represent between 5 and $25 \%$ of the BW and it varies mainly according to body weight and diet. In fact, in comparison to this study, the database of the NRC (2000) is composed of heavier animals and receiving diets less fibrous, which tends to reduce the digesta content.

Under normal feeding (ad libitum group), intake would not influence the digesta content (Rohr \& Daenicke, 1984). However, the intake is associated positively with body weight and negatively to the retention time of digesta in the gastrointestinal tract (Mertens \& Ely 1979). Thus, in contrasting levels of feeding (ad libitum vs. restricted), differences in intake could affect the digesta content (Owens et al., 1993).

Table 2 - Estimated regression coefficients and standard errors for equations $(y=\zeta \mathrm{x})$ fitted to the body and carcass relations between

\begin{tabular}{|c|c|c|c|c|}
\hline \multicolumn{2}{|c|}{$\mathrm{SBW} \times \mathrm{BW}$} & \multicolumn{3}{|c|}{$\mathrm{EBW} \times \mathrm{BW}$} \\
\hline Feeding Management & $\hat{\zeta}$ & Feeding Management & & $\hat{\zeta}$ \\
\hline Restricted & $0.945 \pm 0.006^{\mathrm{ns}}$ & Restricted & 0.769 & $\pm 0.005^{*}$ \\
\hline Ad libitum & $0.950 \pm 0.008$ & Ad libitum & 0.802 & \pm 0.009 \\
\hline \multicolumn{2}{|c|}{$\mathrm{EBW} \times \mathrm{SBW}$} & \multicolumn{3}{|c|}{$\mathrm{CW} \times \mathrm{SBW}$} \\
\hline Feeding Management & $\hat{\zeta}$ & Feeding Management & & $\hat{\zeta}$ \\
\hline Restricted & $0.812 \pm 0.006^{*}$ & Restricted & 0.546 & $\pm 0.004^{*}$ \\
\hline Ad libitum & $0.843 \pm 0.008$ & Ad libitum & 0.560 & \pm 0.006 \\
\hline
\end{tabular}
weights ${ }^{1,2}$

1 Equation passing through origin.

${ }^{2}$ Non significant differences (ns) or significant at the level of $5 \%(*)$ by $t$ test, among the estimated parameters (restricted versus ad libitum). 
In this study, the loss of digesta in the first 16 hours of fasting (BW - SBW), in proportion to the total weight of digesta (BW - EBW), was 21.6 and $25.2 \%$ for restricted and ad libitum groups, respectively (Table 2). This would indicate that in animals under restriction, the passage rate was lower and, therefore, the retention time of digesta was higher. In fact, the higher content of digesta in restricted animals, compared to ad libitum animals, have been attributed to a reduction in the rate of passage (Sainz, 1998, Fontes et al., 2007). This same principle could be observed, conversely, with increasing passage rate, due to the pelletization of diet, which would result in a reduction in the digesta content (Mertens \& Ely 1979; Daenicke \& Rohr, 1984).

Nellore and crossbred did not differ $(\mathrm{P}>0.05)$ on the body proportions of internal organs (liver, heart, kidneys, lungs and spleen) and liver. However, the body proportions of the gastrointestinal tract (rumen, reticulum, omasum, abomasum and small and large intestines) was higher $(\mathrm{P}<0.05)$ in crossbred compared to Nellore. There was no interaction effect $(\mathrm{P}>0.05)$ of genetic group $\times$ feeding management (Table 3).

The weights of internal organs and viscera would increase in response to the energy intake (Sprinkle et al., 1998) and they would be positively associated with energy requirements of animals (Sainz, 1998). In this sense, the isolated analysis of the liver was justified because of the greater energy demands of this organ in particular (Johnson et al., 1990).

In studies with animals fed diets with high energy content in contrasting levels of intake (ad libitum vs. restricted), it has been observed interactions between genetic group $\times$ level of intake on weights of organs and viscera, showing differences between breeds only in animals fed ad libitum (Fortin et al. 1980; Ferrel \& Jenkins, 1998a,b).
In this study, the energy density of forage (1.9 Mcal $\mathrm{ME} / \mathrm{kg} \mathrm{DM}$ ), relatively low compared to that of concentrated diets, possibly limited the expression of genetic differences between the groups studied, even for animals fed ad libitum. The lower weight of the gastrointestinal tract was observed in Nellore animals (Table 3) would not be related to food intake, but to the adaptation of Bos indicus breeds to hot climate (Sprinkle et al., 1998). Thus, regardless to the level of feeding (restricted and ad libitum), Ferrel \& Jenkins (1998b) found that the weight of the gastrointestinal tract was higher for the Angus as compared to the Boran and Tuli cattle, breeds adapted to the hot climate.

Body proportions of the gastrointestinal tract, liver and internal organs were higher $(\mathrm{P}<0.05)$ in reference group and not different $(\mathrm{P}>0.05)$ between the restricted and ad libitum animals (Table 3). However, there was a tendency $(\mathrm{P}<0.10)$ in ad libitum animals to have a higher body proportion of liver.

At first, these results would not confirm the positive influence of intake on weight of organs and viscera (Sprinkle et al., 1998). Moreover, the highest values observed for the reference group, which were slaughtered younger, suggest that the increased maturity was accompanied by a decrease in body proportions of the gastrointestinal tract, liver and internal organs. In fact, for animals in the finishing phase, the rate of growth of organs would be smaller than the rate of growth of the animal as a whole, resulting in a decrease in body proportions of these components (Lawrence \& Fowler, 1997). Thus, the effect of intake, already limited by the energy density of forage, might have been disguised by changes in body composition resulting from the development of the animal.

Table 3 - Means and standard errors for body component (\% EBW) for reference, restricted and ad libitum groups and crossbred Nellore steers ${ }^{1}$

\begin{tabular}{|c|c|c|c|c|}
\hline \multirow[t]{2}{*}{ Breed } & \multicolumn{3}{|c|}{ Feeding management } & \multirow[t]{2}{*}{ Average } \\
\hline & Reference & Restricted & Ad libitum & \\
\hline \multicolumn{5}{|c|}{ Gastrointestinal tract } \\
\hline Nellore & $4.84 \pm 0.15$ & $4.42 \pm 0.15$ & $4.26 \pm 0.15$ & $4.51 \pm 0.09 a$ \\
\hline Crossbred & $5.32 \pm 0.15$ & $4.64 \pm 0.15$ & $4.49 \pm 0.15$ & $4.82 \pm 0.09 b$ \\
\hline Average & $5.08 \pm 0.11 \mathrm{~A}$ & $4.53 \pm 0.11 \mathrm{~B}$ & $4.38 \pm 0.11 \mathrm{~B}$ & \\
\hline \multicolumn{5}{|c|}{ Internal organs } \\
\hline Nellore & $3.03 \pm 0.08$ & $2.59 \pm 0.08$ & $2.67 \pm 0.08$ & $2.76 \pm 0.05 a$ \\
\hline Crossbred & $3.02 \pm 0.08$ & $2.59 \pm 0.08$ & $2.54 \pm 0.08$ & $2.72 \pm 0.05 a$ \\
\hline Average & $3.03 \pm 0.06 \mathrm{~A}$ & $2.59 \pm 0.06 \mathrm{~B}$ & $2.60 \pm 0.06 \mathrm{~B}$ & \\
\hline \multicolumn{5}{|l|}{ Liver } \\
\hline Nellore & $1.28 \pm 0.03$ & $1.06 \pm 0.03$ & $1.13 \pm 0.03$ & $1.16 \pm 0.02 \mathrm{a}$ \\
\hline Crossbred & $1.21 \pm 0.03$ & $1.05 \pm 0.03$ & $1.10 \pm 0.03$ & $1.12 \pm 0.02 \mathrm{a}$ \\
\hline Average & $1.24 \pm 0.02 \mathrm{~A}$ & $1.05 \pm 0.02 \mathrm{~B}$ & $1.12 \pm 0.02 \mathrm{~B}$ & \\
\hline
\end{tabular}

${ }^{1}$ Means followed by different capital letters in the rows and by lower case letters in the columns differ by Tukey test (5\%). 
In addition, although the positive influence of intake on the weight of the gastrointestinal tract had been observed in feedlot animals (Fortin et al. 1980; Ferrel \& Jenkins, 1998a,b), the same could not occur for grazing animals. According to Sainz (1998), the restriction of a food with high fiber content, contrary to what would occur with high energy diets, would not reduce the weight of the gastrointestinal tract, particularly the rumen-reticulum (Sainz, 1998).

There was a tendency $(\mathrm{P}<0.10)$ of crossbreeds to have a higher growth in ribeye area in relation to Nellore; in turn, the Nellore showed higher rates of growth of visceral fat (Table 4). There were no differences between the rates of deposition physical fat (intermuscular and subcutaneous) of Nellore and crossbred (Table 4). Regarding the empty body, the growth of ribeye area $(\gamma=0.67)$ was isometric, while the visceral fat deposition was late $(\gamma>1)$ (Table 4$)$.

By linking allometry of ribeye area (measure twodimensional $-\mathrm{cm}^{2}$ ) to body weight (three-dimensional - $\mathrm{kg}$ ), isometric growth is characterized as $\gamma=2 / 3=0,67$. Besides of being an indicator of carcass muscularity (ratio muscle:bone) (Berg \& Butterfield, 1976), the ribeye area is a measurement associated with the development of a part of great commercial value - the longissimus dorsi muscle. The results of this study confirm the high potential for growth of the longissimus dorsi in continental European breeds, as noted by Ferrell \& Jenkins (1998a).

Results contrary to the ones obtained in this study (Table 4) were reported by Cianzio et al. (1982), who found no differences in the rate of visceral fat deposition between breeds of small and large frames by using European breeds (British and Continental). Moreover, Sprinkle et al. (1998) found higher deposition of visceral fat in the Tuli breed, adapted to hot climates, compared to Angus and Hereford breeds. According to these authors, the degree of adaptation of animal to heat and adverse nutritional conditions would be positively associated with visceral fat deposition.

Considering the overlap of confidence intervals at 95\% [ \pm (standard error $\times t)$ ], there were no differences, in both genetic groups, between the estimated deposition rates (Table 4) for carcass (intermuscular and subcutaneous) and visceral (mesenteric and omental) fat. These results indicate that the deposition of fat in the carcass was accompanied by a similar proportion of visceral fat deposition. However, intermuscular and subcutaneous fat were not measured separately, making it difficult to compare to other researches. According to Cianzio et al. (1982) and Berg \& Walters (1983), the growth rates of intramuscular (marbling), visceral and intermuscular fat would be isometric in relation to growth in total body fat, whereas the growth of subcutaneous fat would happen later. Overall, with the maturity of the animal fat accumulation would move from center to periphery of the body (Sprinkle et al., 1998).

Nellore and crossbreds animals did not differ $(\mathrm{P}>0.05)$ on the concentration of crude protein in empty body, carcass and noncarcass. There was no difference between genetic groups for the concentration of chemical fat in empty body and carcass, but the Nellore had higher concentration of chemical fat in noncarcass. For the body concentration of energy, Nellore tended $(\mathrm{P}<0.10)$ to be higher (empty body), did not differ (carcass) and were higher (noncarcass) to crossbred animals (Table 5).

The trend of Nellore animals to have a higher concentration of energy in the empty body was due to greater chemical fat deposition in noncarcass, according to the results obtained for the deposition of visceral fat (Table 4). However, the deposits of internal fat (kidney, pelvic, heart, mesenteric and omental fat) were not sampled and analyzed separately, which prevented a better understanding of the differences in the deposition rates of fat/energy on noncarcass.

In addition, the allometric equations adjusted for protein and energy in the empty body were derived in order to predict the chemical composition of empty body weight tissue gain (ARC, 1980) (Table 6). Because there are no differences in the concentration of protein in empty body between genetic groups, it was set a joint equation for the estimates of the parameters: $\alpha=0.435$ and $\hat{\gamma}=0.868$. Regarding to the energy, in view of the tendency for

Table 4 - Estimated parameters and standard errors for allometric equations fitted to weights or area of carcass and non carcass components as a function of empty body weight ${ }^{1}$

\begin{tabular}{|c|c|c|c|c|}
\hline & \multicolumn{2}{|c|}{ Crossbred } & \multicolumn{2}{|c|}{ Nellore } \\
\hline & $\log \alpha$ & $\hat{\gamma}$ & $\log \alpha$ & $\hat{\gamma}$ \\
\hline Rib eye area $\left(\mathrm{cm}^{2}\right)$ & $-0.435 \pm 1.38 \dagger$ & $0.894 \pm 0.54 \dagger$ & $2.110 \pm 1.17$ & $0.128 \pm 0.46$ \\
\hline Visceral fat (kg) & $-3.807 \pm 1.45^{*}$ & $1.861 \pm 0.57 *$ & $-7.370 \pm 1.19$ & $3.273 \pm 0.47$ \\
\hline Carcass fat $(\mathrm{kg})^{2}$ & $-4.386 \pm 1.09$ & $2.355 \pm 0.43$ & $-1.843 \pm 1.29$ & $1.356 \pm 0.51$ \\
\hline
\end{tabular}

${ }^{1}$ Significant differences at $10 \%(\dagger)$ or $5 \%(*)$ level by $t$ the test among estimated parameters for Nellore and crossbred steers.

2 Carcass fat $=$ intermuscular fat and subcutaneous fat. 
differences between intercepts $(\mathrm{P}=0.062)$ and allometric coefficients $(\mathrm{P}=0.058)$, individual equations were derived for Nellore and crossbred animals (Tables 5 and 6).

The equations shown in Table 6 were used to predict the body concentrations of protein and energy in the empty body and empty body gain (net requirements for gain) (Table 7).

The Nellore breed has been defined as a medium to large frame and Limousin breed (continental Europe) as large frame (Buchanan \& Dolezal et al., 1999). According Geay (1984) and Fox \& Black (1984), smaller frame animals, even within the same genetic group, would present, on the same empty body weight, lower proportions of protein and higher proportions of fat (and energy) than larger frame animals.

In particular, the fat would present the highest amplitude of variation in body composition, and the diluent effect of fat deposition would be the main factor in reducing the concentration of other body chemical components (protein, water and ash) (Fortin et al. 1980; Fox \& Black, 1984; NRC, 2000).
Berg \& Butterfield (1976) concluded that changes in body composition among genetic groups were resulted by differences as to when the fattening phase begins, and the intensity of the fat deposition rates during the fattening phase, or the combination of both factors. In Brazil, in conditions of confinement, Nellore animals have shown higher rates of fat deposition during fattening phase, in comparison to its crosses with larger breeds (Fontes, 1995).

In this study, the absence of differences in the body concentrations of protein and fat, in empty body and carcass (Table 5), would not confirm the supposed precocity of Nellore in relation to their crosses with larger frame breeds. However, the relationship between body compositions of genetic groups would be variable, in view of the interactions between genetic group $\times$ growth curve (Barber et al., 1981) and genetic group $\times$ feeding level (Fortin et al. 1980; Ferrell \& Jenkins, 1998a,b).

In a study with small (Angus) and large (Charolais) frame breeds, slaughtered at different weights, Barber et al. (1981) found differences among breeds regarding body content fat only when the animals had median

Table 5 - Estimated parameters and standard errors for equations fitted to allometric chemical component contents of empty body, carcass and noncarcass, as a function of empty body weight

\begin{tabular}{|c|c|c|c|c|c|c|c|}
\hline & \multirow[t]{2}{*}{ Breed } & \multicolumn{2}{|c|}{ Crude protein } & \multicolumn{2}{|c|}{ Chemical fat } & \multicolumn{2}{|c|}{ Energy } \\
\hline & & $\log \alpha$ & $\hat{\gamma}$ & $\log \alpha$ & $\hat{\gamma}$ & $\log \alpha$ & $\hat{\gamma}$ \\
\hline Empty body & $\begin{array}{l}\text { Crossbred } \\
\text { Nellore }\end{array}$ & $\begin{array}{l}-0.383 \pm 0.32 \mathrm{~ns} \\
-0.207 \pm 0.27\end{array}$ & $\begin{array}{l}0.878 \pm 0.13 \text { ns } \\
0.805 \pm 0.11\end{array}$ & $\begin{array}{l}-5.640 \pm 1.87 \mathrm{~ns} \\
-8.519 \pm 1.57\end{array}$ & $\begin{array}{l}2.846 \pm 0.73 \mathrm{~ns} \\
4.005 \pm 0.62\end{array}$ & $\begin{array}{l}-1.796 \pm 0.83 \dagger \\
-3.434 \pm 0.70\end{array}$ & $\begin{array}{l}1.844 \pm 0.33 \dagger \\
2.499 \pm 0.27\end{array}$ \\
\hline Carcass & $\begin{array}{l}\text { Crossbred } \\
\text { Nellore }\end{array}$ & $\begin{array}{l}-0.489 \pm 0.51 \mathrm{~ns} \\
-0.395 \pm 0.43\end{array}$ & $\begin{array}{l}0.845 \pm 0.20 \mathrm{~ns} \\
0.804 \pm 0.17\end{array}$ & $\begin{array}{l}-6.525 \pm 2.53 \mathrm{~ns} \\
-8.879 \pm 2.13\end{array}$ & $\begin{array}{l}3.111 \pm 0.99 \mathrm{~ns} \\
4.068 \pm 0.84\end{array}$ & $\begin{array}{l}-2.171 \pm 1.18 \mathrm{~ns} \\
-3.749 \pm 0.99\end{array}$ & $\begin{array}{l}1.914 \pm 0.46 \text { ns } \\
2.546 \pm 0.39\end{array}$ \\
\hline Noncarcass & $\begin{array}{l}\text { Crossbred } \\
\text { Nellore }\end{array}$ & $\begin{array}{l}-1.004 \pm 0.39 \mathrm{~ns} \\
-0.643 \pm 0.33\end{array}$ & $\begin{array}{l}0.943 \pm 0.15 \mathrm{~ns} \\
0.800 \pm 0.13\end{array}$ & $\begin{array}{l}-4.998 \pm 1.56^{----*} \\
-8.875 \pm 1.31\end{array}$ & $\begin{array}{l}2.429 \pm 0.61 * \\
3.927 \pm 0.52\end{array}$ & $\begin{array}{l}-1.931 \pm 0.72 * \\
-3.664 \pm 0.61\end{array}$ & $\begin{array}{l}1.724 \pm 0.28 * \\
2.416 \pm 0.24\end{array}$ \\
\hline
\end{tabular}

${ }^{1}$ Non significant differences (ns), significant at $5 \%(*)$ or $10 \%(\dagger)$ level by $t$ test among estimate of the parameters (Nellore vs. Crossbred).

Table 6 - Prediction equations of energy and protein contents in the empty body and in weight gain (net requirements) (Y and Y ') as a function of empty body weight $(\mathrm{X})$

\begin{tabular}{|c|c|c|c|}
\hline & & Body composition & Composition of gain \\
\hline Protein & Pooled & $\log Y=-0.358+0.868 \times \log X$ & $Y^{\prime}=0.868 \times 0.435 \times X^{-0.132}$ \\
\hline Energy & $\begin{array}{l}\text { Nellore } \\
\text { Crossbred }\end{array}$ & $\begin{array}{l}\log Y=-3.434+2.499 \times \log X \\
\log Y=-1.796+1.844 \times \log X\end{array}$ & $\begin{array}{l}Y^{\prime}=2.499 \times 0.0004 \times \mathrm{X}^{-1.499} \\
\mathrm{Y}^{\prime}=1.844 \times 0.016 \times \mathrm{X}^{-0.844}\end{array}$ \\
\hline
\end{tabular}

Table 7 - Proportions of protein and energy in the empty body and in weight gain (net requirements) for Nellore and crossbred steers, as a function of the empty body weight (EBW)

\begin{tabular}{|c|c|c|c|c|c|c|}
\hline \multirow[b]{3}{*}{ EBW (kg) } & \multicolumn{2}{|c|}{ Protein $(\mathrm{g} / \mathrm{kg})^{1}$} & \multicolumn{4}{|c|}{ Energy (Mcal/kg) } \\
\hline & \multirow{2}{*}{$\begin{array}{c}\text { Empty body } \\
\text { Pooled }\end{array}$} & \multirow{2}{*}{$\begin{array}{c}\text { Gain } \\
\text { Pooled }\end{array}$} & \multicolumn{2}{|c|}{ Empty body } & \multicolumn{2}{|c|}{ Gain } \\
\hline & & & Nellore & Crossbreed & Nellore & Crossbreed \\
\hline 300 & 205 & 178 & 2.1 & 2.0 & 5.2 & 3.6 \\
\hline 350 & 201 & 174 & 2.6 & 2.2 & 6.5 & 4.1 \\
\hline 400 & 197 & 171 & 3.2 & 2.5 & 7.9 & 4.6 \\
\hline 450 & 194 & 169 & 3.8 & 2.8 & 9.5 & 5.1 \\
\hline
\end{tabular}


weights - coinciding with the period of increased fat deposition in Angus animals. There were no differences in body composition at higher weights because, according to the authors, the evaluated weight intervals had not entirely included the phase of greater fat deposition in Charolais animals.

In this study, the evaluated weight interval (Table 1) probably included the stage of greater fat deposition of both genetic groups. This is because the fat deposition rates $(\gamma)$ in the observed empty body (Table 5) for Nellore $(\gamma=4.005)$ and crossbreed $(\gamma=2.846)$, were relatively high compared to those described in the Brazilian literature (Fontes, 1995 and Silva et al. , 2002, Backes et al., 2005, Goulart et al., 2008).

By assessing the body composition of Angus and Friesian steers at two feeding levels (ad libitum vs. 65-70\% ad libitum), Fortin et al. (1980) reported that differences in fat body content between genetic groups were observed only at ad libitum feeding level. The authors concluded that at low levels of energy intake the animals do not express their full genetic potential for fat deposition. In this regard, the AFRC (1991) concluded that the expression of the genotype requires non-limiting environmental conditions, otherwise, there would be a risk that the results would describe the environment and not the animal.

The rate of weight gain in animals on pasture, even under optimal conditions, would be moderate in relation to confined animals (Poppi \& McLennan, 1995; Ferrell \& Jenkins et al., 1998a, b; Ribeiro et al., 2008; Garcia et al., 2011). The rate of gain would be strongly and positively associated to fat deposition (NRC, 2000), which would explain mainly the lower body concentration of fat and higher body concentration of protein in grazing animals (Table 6), compared to confined animals (Fontes, 1995; Zervoudakis et al. 2002; Fontes et al., 2005b). This pattern, however, would not result only by the lowest rates of weight gain, but also by the direct effect of grazing on body composition (Hata et al., 2005).

In this study, the experimental animals were purchased from a commercial breeder, which adopts management practices typical of extensive pasture production systems. Thus, during the rearing and growth phases, the growth curve of the animals would have followed the seasonal forage supply, delaying the beginning of fattening phase. In the partition of energy, the maintenance would be a priority, followed by the growth of bones, muscles and finally the fat deposition (Berg \& Butterfield, 1976).

When the animals were transferred to the experimental conditions, they had daily access to high amounts of green leaves (8 kg DM /100 kg BW), which would have provided the energy necessary for the increased fat deposition, particularly for Nellore animals. In the crossbreed animals, which would have higher potential for growth (larger frame breed), apparently a greater proportion of energy was directed toward muscle development, resting less energy for fat deposition. In fact, in this study, the deposition rates $(\gamma)$ of lean meat in carcass differed $(\mathrm{P}<0.05)$ among genetic groups, being observed values of $1.014 \pm 0.10$ (crossbreed) and $0.789 \pm 0.09$ (Nellore).

Thus, it is possible that the limited energy intake on pasture had delayed the onset of the fattening phase in both genetic groups, preventing the expression of possible differences between the Nellore and crossbred animals. Moreover, the deposition rates $(\gamma)$ of fat/energy observed in this study (Table 5) suggest that the differences between the Nellore and crossbreed animals were related mainly to the increased intensity of the deposition of fat/energy in the Nellore animals during the fattening phase.

The evaluation of animals after a sudden change of environment is commonly observed in studies conducted in Brazil, particularly from extensive grazing to feedlot . This could partly explain the high rates of fat deposition $(\gamma)$ observed in Brazilian studies (Fontes, 1995 and Silva et al., 2002), in comparison, within breed and frame, to studies conducted in countries which adopt more intensive production systems, a common practice in the feedlot after weaning (Fortin et al. 1980; Daenicke \& Rohr, 1984).

As it was previously noted, fat deposition rates $(\gamma)$ were relatively high in this study. On the other hand, the values of the intercepts $(\log \alpha)$ were relatively low (Table 5) when compared with Brazilian literature, which evaluate, almost entirely, feedlot animals (Fontes, 1995; Véras et al. 2000 and Silva et al. 2002; Backes et al. 2005; Goulart et al., 2008). At first, this might suggest that variations between the intercepts $(\log \alpha)$ would be associated with differences in the beginning of the fattening phase, whereas variations between allometric coefficients $(\gamma)$ would be associated with differences in intensity of the fat deposition rate during fattening phase. However, it would not be simple to identify trends by assigning different meanings for each parameter individually. In fact, there is a strong negative correlation between the parameters $(\alpha, \gamma)$, which, according to Kidwell et al. (1952) would be required to the good fit of the allometric curve and indicates that both parameters are measurements from the same biological phenomenon.

\section{Conclusions}

Nellore animals deposit more energy in the gain than their crosses with breeds of large frame. It is possible to 
obtain well finished carcasses of Nellore cattle and their crosses with large breed in tropical pastures with adequate supply of green leaves.

\section{Acknowledgments}

To the staff of UENF: Antonio Pereira de Souza, Cristiano Ferreira Moço, Sergio Ribeiro Americo Morais and Eliziel Borges Barbosa, who made the realization of this study possible.

\section{References}

AGRICULTURAL AND FOOD RESEARCH COUNCIL - AFRC. Technical committee on responses to nutrients. Report 7 . Theory of response to nutrients by farm animals. Growth. Nutrition Abstracts and Reviews (Series B), n.10, v.61, p.683-722, 1991.

AGRICULTURAL RESEARCH COUNCIL - ARC. The nutrient requirements of ruminants. London: 1980. 351p.

BACKES, A.A.; PAULINO, M.F.; ALVES, D.D. et al. Composição corporal e exigências energéticas e protéicas de bovinos mestiços leiteiros e zebu, castrados, em regime de recria e engorda. Revista Brasileira de Zootecnia, v.34, n.1, p.257-267, 2005.

BARBER, K.A.; WILSON, L.L.; ZIEGLER, J.H. et al. Charolais and angus steers slaughtered at equal percentages of mature cow weight. II. Empty body composition, energetic efficiency and comparison of compositionally similar body weights. Journal of Animal Science, v.53, n.4, p.766-906, 1981.

BERG, R.T.; BUTTERFIELD, R.M. New concepts of cattle growth. New York: Sydney University, 1976. 240p.

BERG, R.T.; WALTERS, L.E. The meat animal: changes and challenges. Journal of Animal Science, v.57, n.2, p.133-146, 1983.

BRASIL. Ministério da Agricultura. Instrução Normativa no. 3, de 07 de janeiro de 2000. Regulamento técnico de métodos de insensibilização para o abate humanitário de animais de açougue. S.D.A./M.A.A. Diário Oficial da União, Brasília, p.14-16, 24 de janeiro de 2000, Seção I. Disponível em: <www. agricultura.gov.br/das/dipoa/Anexo\%20Abate.htm>. Acesso em: $19 / 4 / 2008$.

BUCHANAN, D.S.; DOLEZAL, S.L. Breeds of cattle. In: FRIES, R.; RUVINSKY, A. (Eds.) The genetics of cattle. 1.ed. New York: CAB International: 1999. p.667-695.

CIANZIO, D.S.; TOPEL, D.G.; WHITEHURST, G.B. et al. Adipose tissue growth in cattle representing two frame sizes: distribution among depots. Journal of Animal Science, v.55, n.2, p.305-312, 1982.

FERRELL, C.L.; JENKINS, T.G. Body composition and energy utilization by steers of diverse genotypes fed a high-concentrate diet during the finishing period: I. angus, belgian blue, hereford, and piemontese sires. Journal of Animal Science, v.76, n.2, p.637-646, 1998a.

FERRELL, C.L.; JENKINS, T.G. Body composition and energy utilization by steers of diverse genotypes fed a high-concentrate diet during the finishing period: II. angus, boran, brahman, hereford, and tuli sires. Journal of Animal Science, v.76, n.2, p.647-657, 1998b.

FONTES, C.A.A.; GUIMARÃES, R.F.M.; ALMEIDA, M.I.V. et al. Avaliação do ganho compensatório em novilhos mestiços Holandês-Gir: consumo e desempenho. Revista Brasileira de Zootecnia, v.36, n.3, p.698-708, 2007.

FONTES, C.A.A.; OLIVEIRA, R.C.; ERBESDOBLER, E.D. et al. Conteúdo de energia líquida para mantença e ganho do capimelefante e mudanças na composição corporal de novilhos em pastejo, durante a estação chuvosa. Revista Brasileira de Zootecnia, v.34, n.5, p.1711-1720, 2005b.

FONTES, C.A.A.; OLIVEIRA, R.C.; ERBESDOBLER, E.D. et al. Uso do abate comparativo na determinação da exigência de energia de mantença de gado de corte pastejando capim-elefante: descrição da metodologia e dos resultados. Revista Brasileira de Zootecnia, v.34, n.5, p.1721-1729, 2005a.

FONTES, C.A.A. Composição corporal, exigências líquidas de nutrientes para ganho de peso e desempenho produtivo de animais zebuinos e mestiços europeu - zebu. Resultados experimentais. In: SIMPÓSIO INTERNACIONAL SOBRE EXIGÊNCIAS NUTRICIONAIS DE RUMINANTES, 1995, VIÇOSA, MG. Anais... Viçosa, MG: JARD, 1995. p.419-455.

FORTIN, A.; SIMPFENDORFER, S.; REID, J.T. et al. Effect of level of energy intake and influence of breed and sex on the chemical composition of cattle. Journal of Animal Science, v.51, n.3, p.604-614, 1980.

FOX, D.G.; BLACK, J.R. A system for predicting body composition and performance of growing cattle. Journal of Animal Science, v.58, n.3, p.725-739, 1984.

GARCIA, C.S.; FERNANDES, A.M.; FONTES, C.A.A. et al. Desempenho de novilhos mantidos em pastagens de capimelefante e capim-mombaça. Revista Brasileira de Zootecnia, v.40, n.2, p.403-410, 2011.

GEAY, Y. Energy and protein utilization in growing cattle. Journal of Animal Science, v.58, n.3, p.766-778, 1984.

GOULART, R.S.; ALENCAR, M.M.; POTT, E.B. et al. Composição corporal e exigências líquidas de proteína e energia de bovinos de quatro grupos genéticos terminados em confinamento. Revista Brasileira de Zootecnia, v.37, n.5, p.926-935, 2008.

HANKINS, O.G.; HOWE, P.E. Estimation of the composition of beef carcasses and cuts. Washington, D.C., 1946. (Tech. Bulletin - USDA, 926). 20p.

HATA, H.; SUZUKI, K.; TOMIOKA, T. et al. Effects of grazing on deposition of chemical body components, energy retention and plasma hormones in steers. Animal Science Journal, v.76, n.5, p.225-236, 2005.

JOHNSON, D.E.; KRISTEN, J.A.; BALDWIN, R. L. Changes in liver and gastrointestinal tract energy demands in response to physiological workload in ruminants. Journal of Nutrition, v.120, n.2, p.649-655, 1990.

KIDWELL, J.F.; GREGORY, P.W.; GUILBERT, H.R. A genetic investigation of allometric growth in hereford cattle. Genetics, v.37, n.2, p.158-174, 1952.

KOCK, S.W.; PRESTON, R.L. Estimation of bovine carcass composition by the urea dilution technique. Journal of Animal Science, v.48, n.2, p.319-327, 1979.

LAWRENCE, T.L.J.; FOWLER, V.R. Growth of farm animals. 2.ed. New York: CAB International, 1997. 330p.

LOFGREEN, G.P.; GARRETT, W.N. A system for expressing net energy requeriments and feed values for growing and finishing beef cattle. Journal of Animal Science, v.27, n.3, p.793-806, 1968.

MERTENS, D.R.; ELY, L.O. A dynamic model of fiber digestion and passage in the ruminant for evaluating forage quality. Journal of Animal Science, v.49, n.4, p.1085-1095, 1979.

NATIONAL RESEARCH COUNCIL - NRC. Nutrient requirement of beef cattle. 7.ed. update. Washington, D.C.: National Academy Press, 2000. 247p.

OWENS, F.N.; DUBESKI, P.; HANSON, C.F. Factors that the growth and development of ruminants. Journal of Animal Science, v.71, n.11, p.3138-3150, 1993.

POPPI, D.P.; McLENNAN, S.R. Protein and energy utilization by ruminants at pasture. Journal of Animal Science, v.73, n.1, p.278-290, 1995.

RIBEIRO, E.G.; FONTES, C.A.A.; PALIERAQUI, J.G.B. et al. Influência da irrigação, durante as épocas seca e chuvosa, na taxa de lotação, consumo e desempenho de novilhos em pastagens dos capim-elefante e capim-mombaça. Revista Brasileira de Zootecnia, v.37, n.9, p.1546-1554, 2008. 
ROHR, K.; DAENICKE, R. Nutritional effects on the distribution of live weight as gastrointestinal tract fill and tissue components in growing cattle. Journal of Animal Science, v.58, n.4, p.753-765, 1984.

SAINZ, R.D. Crescimento compensatório em bovinos. In: SIMPÓSIO SOBRE PRODUÇÃO INTENSIVA DE GADO DE CORTE, 1998, Campinas. Anais... Campinas: CBNA, 1998. p.22-38.

SILVA, D.J.; QUEIROZ, A.C. Análise de alimentos (métodos químicos e biológicos). 2.ed. Viçosa, MG: Universidade Federal de Viçosa, 2002. 235p.

SILVA, F.F.; VALADARES FILHO, S.C.; ÍTAVO, L.C.V. et al. Exigências líquidas e dietéticas de energia, proteína e macroelementos minerais de bovinos de corte no brasil. Revista Brasileira de Zootecnia, v.31, n.2, p.776-792, 2002.

SPRINKLE, J.E.; FERRELL, C.L.; HOLLOWAY, J.W. et al. Adipose tissue partitioning of limit-fed beef cattle and beef cattle with ad libitum access to feed differing in adaptation to heat. Journal of Animal Science, v.76, n.2, p.665-673, 1998.

VALADARES FILHO, S.C.; MAGALHÃES, K.A.; ROCHA JÚNIOR, V.R. et al. Tabelas brasileiras de composição de alimentos para bovinos. 2.ed. Viçosa, MG: UFV, 2006. $392 \mathrm{p}$.

VÉRAS, A.S.C.; VALADARES FILHO, S.C.; SILVA, J.F.C. et al. Composição corporal e requisitos energéticos e protéicos de bovinos nelore, não-castrados, alimentados com rações contendo diferentes níveis de concentrado. Revista Brasileira de Zootecnia, v.29, n.6, p.2379-2389, 2000.

ZERVOUDAKIS, J.T.; PAULINO, M.F.; DETMANN, E. et al. Conteúdo corporal e exigências líquidas de proteína e energia de novilhos suplementados no período das águas. Revista Brasileira de Zootecnia, v.31, n.1, p.530-537, 2002. 